\title{
The effect of natural sugar and sweeteners on normal and cancerous human fibroblasts
}

\begin{abstract}
Non-nutritive sweeteners (NNS) have seen increasingly common usage amongst foodstuffs in the westernized diet in the past few decades, including processed foods and flavored beverages. Recently, an increasing body of research has been evaluating the potential of NNS for alternative uses in healthcare and medicine. Some of these sweeteners, such as stevioside, have been implicated as being anti-hypertensive, anti-carcinogenic, and antiinflammatory in several contexts. To examine the potential of NNS such as stevioside as an anti-carcinogenic agent, cellular behavior of HFF-1 human foreskin fibroblasts (ATCC SCRC-1041) \& COLO-829 human melanoma fibroblasts (ATCC CRL-1974) was observed in the presence of sucrose, sucralose, and stevioside on collagen. This study examined the impact of NNS on initial adhesion, cellular proliferation, and integrin expression on healthy and cancerous fibroblast cell lines. The results indicate that $5 \mathrm{mg} / \mathrm{mL}$ stevioside caused more than 2-fold decrease in the initial adhesion of healthy cells but caused more than 4-fold increase in the initial adhesion of cancerous cells. In terms of proliferation, stevioside at $5 \mathrm{mg} / \mathrm{mL}$ caused a 13 -fold decrease in cancer cell proliferation, proportional to concentration, but a 1.5 -fold increase in proliferation for healthy cells.
\end{abstract}

Keywords: HFF-1, human foreskin fibroblasts, stevioside, sucralose sucrose, nonnutritive sweeteners
Volume 6 Issue 5 - 2019

\author{
Kircher Eric,' Lee Jeffrey,' Wang He Choil,' \\ Tawil Bill',2 \\ 'Department of Biotechnology and Bioinformatics, California \\ State University, USA \\ ${ }^{2}$ Department of Biomedical Engineering, University of California \\ Los Angeles, USA \\ *These authors contributed equally to this work.
}

Correspondence: Bill Tawil, Department of Bioengineering, UCLA School of Engineering, 420 Westwood Plaza, Room 5121, Engineering V. P.O. Box: 951600, Los Angeles, CA 90095-1600, USA, Fax (310) 794-5956, Email bill.tawil@csuci.edu

Received: August 18,2019 | Published: September 03, 2019
Abbreviations: HFF-1, human foreskin fibroblast; COLO829, melanoma human foreskin fibroblast; NNS, non-nutritive sweeteners; CL, collagen; FACS, fluorescence-activated cell sorting; PBS, phosphate buffer saline; 24-well plate, 24-well cluster.

\section{Introduction}

Diabetes and obesity have become increasingly common diseases in the westernized world over the past 50 years, with over 30 million people in the United States suffering from diabetes and 93 million who are obese. ${ }^{1}$ The increasing prevalence of these conditions has led some individuals to seek out sugar alternatives to lessen their total sugar consumption and reduce the risk for these diseases. ${ }^{2}$ The use of nonnutritive sweeteners as a substitute for natural sugar began as early as 1878 when Ramsen and Fahlberg discovered the artificial sweetener saccharin. ${ }^{3}$ The use of artificial sugars became more popularized over the next century, especially during several sugar shortages during World War II. ${ }^{4}$ As a result, the use of NNS is ubiquitous in modernday foodstuffs, with many alternatives, zero-calorie sweeteners being used in drinks and processed foods. ${ }^{2}$ Although many studies have been undertaken to evaluate the toxicological and epidemiological profiles of these sweeteners, only recently has research branched out to evaluate potential alternative uses of these compounds. Recent research has focused on the potential uses of certain sweeteners, such as stevioside, to treat some conditions, including diabetes, heart disease, and even cancer. ${ }^{5-8}$ While there is still much research to be done in these areas, early results demonstrate the overall positive effects these compounds may have in medical research.

Sucralose is a sucrose derivative created by selective chlorination of hydroxyl groups on the sugar molecule, inhibiting the body's ability to digest it. When ingested, $8-20 \%$ of sucralose is absorbed into the blood where it is processed by the kidneys. The remaining sucralose passes through the gastrointestinal tract, relatively unchanged. ${ }^{9}$
Besides, sucralose demonstrates low levels of bioaccumulation and peak plasma levels remain consistent, regardless of dose. ${ }^{9,10}$ Peak plasma concentrations occur about 1-3 hours after oral induction, and average around $262 \mathrm{ng} / \mathrm{mL} .{ }^{11}$ In terms of cytotoxicity, some studies have indicated no genotoxicity in the presence of sucralose ${ }^{12}$ whereas others have reported significant cytotoxicity and genotoxicity, especially in intestinal epithelial cells. ${ }^{13}$

Stevioside is an extract of the plant $S$. rebaudiana bertoni that consists of a diterpenic steviol core and many auxiliary glycoside chains. ${ }^{14}$ In the body, stevioside is metabolized by the small intestine, liver, and kidneys, although very little of the substance is absorbed into the blood. ${ }^{7}$ A 2007 study on the metabolism of stevioside found that there are three major byproducts in the body after ingestion of stevioside; namely, steviol in the intestine, unchanged stevioside in the intestine, and approximately $205 \mathrm{mg}$ /hour of steviol glucuronide in the urine, amongst others. ${ }^{14}$ It has been confirmed several times that a large part of the metabolism into steviol and its constituent glycoside chains occurs in large part due to gut microbiota, as humans lack the enzymes to metabolize the compound. ${ }^{5,14}$

In a physiological context, stevioside have been implicated as being anti-hypertensive, cardiotonic, anti-carcinogenic, and antiinflammatory in several contexts. ${ }^{5-8}$ Many researchers are investigating their anti-carcinogenic properties and they have been proposed, albeit tentatively, as potential anti-cancer drugs. Unlike many other natural sweeteners, there seems to be some level of consensus as to the safety of consumption of stevioside..$^{5,7,14}$ This, in conjunction with its natural rather than synthetic origin, has made stevia the sweetener of choice for many consumers. Given the emerging research into the potential anti-carcinogenic effects of some NNS, we have undertaken a pilot study on the effects of stevioside and sucralose on the behavior of human melanoma cells. 


\section{Materials and methods}

\section{Scaffold selection}

All materials and methods were performed according to those previously published by Eckhart, Vaghasia, Kniseley, Bucci, \& Tawil. To select for the most optimal scaffold for observing initial cellular adhesion and proliferation in HFF-1 cells, four different scaffolds were prepared: $5 \mu \mathrm{g} / \mathrm{mL}$ collagen, $10 \mu \mathrm{g} / \mathrm{mL}$ collagen, $5 \mu \mathrm{g} / \mathrm{mL}$ fibronectin, and $10 \mu \mathrm{g} / \mathrm{mL}$ fibronectin. It was observed that while the $5 \mu \mathrm{g} / \mathrm{mL}$ fibronectin scaffold exhibited the greatest percent increase in cellular adhesion, the scaffold coated with $10 \mu \mathrm{g} / \mathrm{mL}$ collagen had the largest increase in percent cellular proliferation; thus, the $10 \mu \mathrm{g}$ / $\mathrm{mL}$ collagen scaffold was selected for the entirety of the experiment.

\section{Preparation of sugar stock solutions}

To prepare stock solutions for cell proliferation studies, $400 \mathrm{mg}$ of each sweetener (sucrose (Kroger), sucralose (Sigma Aldrich, 69293-100G), and stevioside (Sigma Aldrich, CDS020802-1G) was dissolved in $10 \mathrm{~mL} \mathrm{HFF-1}$ or Melanoma media to a concentration of $40 \mathrm{mg} / \mathrm{mL}$. This stock solution was filtered through a $0.22 \mu \mathrm{m}$ PVDF syringe filter to sterilize the media under a biosafety cabinet. Next, varying dilutions of each sweetener were made using sterile HFF or Melanoma media under a biosafety cabinet. In previous experiments, stevioside and sucralose stock solutions were initially created in a larger range of concentrations: $0 \mathrm{mg} / \mathrm{mL}, 5.0 \mathrm{mg} / \mathrm{mL}, 10.0$ $\mathrm{mg} / \mathrm{mL}$, and $20.0 \mathrm{mg} / \mathrm{mL}$. We observed that HFF-1 cells could not reach confluency in media with $20.0 \mathrm{mg} / \mathrm{mL}$ stevioside or sucralose. Moving forward, our team lowered the upper limit concentration of the stevioside stock solution from $20.0 \mathrm{mg} / \mathrm{mL}$ to $15.0 \mathrm{mg} / \mathrm{mL}$ and adjusted the sucralose stock concentrations to $0 \mathrm{mg} / \mathrm{mL}, 1 \mathrm{mg} / \mathrm{mL}, 2.5$ $\mathrm{mg} / \mathrm{mL}$, and $5.0 \mathrm{mg} / \mathrm{mL}$.

\section{Dilution series of stevioside}

Stevioside stock solutions were created in HFF-1 and Melanoma media and filtered through Nalgene ${ }^{\mathrm{TM}} 25 \mathrm{~mm}$ Syringe Filters (Thermo ScientificTM, Waltham, MA, USA). $0 \mathrm{mg} / \mathrm{mL}, 5.0 \mathrm{mg} / \mathrm{mL}, 10.0 \mathrm{mg} /$ $\mathrm{mL}$, and $15.0 \mathrm{mg} / \mathrm{mL}$ concentrations of stevioside were prepared from a standard stock $(30 \mathrm{mg} / \mathrm{mL})$ by making serial dilutions. The $\mathrm{pH}$ of each solution was measured. HFF-1 and COLO-829 cells with initial cell densities of 10,000 per well were seeded in 24 -well culture clusters coated with $10 \mu \mathrm{g} / \mathrm{mL}$ collagen and grown in HFF-1 and Melanoma media. All three plates for day 1, day 3, and day 7 were prepared by the same method and placed inside the incubator at $371^{\circ} \mathrm{C}$ with $5 \% \mathrm{CO}_{2}$.

\section{Dilution series of sucralose}

Sucralose stock solutions were created in HFF-1 and Melanoma media and filtered through Nalgene ${ }^{\mathrm{TM}} 25 \mathrm{~mm}$ Syringe Filters (Thermo ScientificTM, Waltham, MA, USA). $0 \mathrm{mg} / \mathrm{mL}, 1.0 \mathrm{mg} / \mathrm{mL}, 2.5 \mathrm{mg} /$ $\mathrm{mL}$, and $5.0 \mathrm{mg} / \mathrm{mL}$ concentrations of sucralose were prepared from a standard stock $(10 \mathrm{mg} / \mathrm{mL})$ by making serial dilutions. The $\mathrm{pH}$ of each solution was measured. HFF-1 and COLO-829 cells with initial cell densities of 10,000 per well were seeded in 24-well culture clusters coated with $10 \mu \mathrm{g} / \mathrm{mL}$ collagen and grown in HFF-1 and Melanoma media. All three plates for day 1, day 3 and day 7 were prepared by the same method and placed inside the incubator at $37{ }^{\circ} \mathrm{C}$ with $5 \% \mathrm{CO}_{2}$.

\section{Dilution series of sucrose}

Sucrose stock solutions were created in HFF-1 and Melanoma media and filtered through Nalgene ${ }^{\mathrm{TM}} 25 \mathrm{~mm}$ Syringe Filters (Thermo
ScientificTM, Waltham, MA, USA). $10.0 \mathrm{mg} / \mathrm{mL}$ concentration of sucrose was prepared. The $\mathrm{pH}$ of each solution was measured. HFF-1 and COLO-829 cells with initial cell densities of 10,000 per well were seeded in 24-well culture clusters coated with $10 \mu \mathrm{g} / \mathrm{mL}$ collagen and grown in HFF-1 and Melanoma media. All three plates for day 1, day 3 and day 7 were prepared by the same method and placed inside the incubator at $37{ }^{\circ} \mathrm{C}$ with $5 \% \mathrm{CO}_{2}$.

\section{HFF-I and COLO-829 cell culture}

As described previously, ${ }_{15}^{15}$ HFF-1 and COLO-829 cultured cells were prepared separately in $75 \mathrm{~cm}$ Vented Flasks (Thermo Scientific, Waltham, MA, USA). Once confluency of the cells has been confirmed via phase-contrast microscopy (Olympus ${ }^{\circledR}$, Shinjuku, Tokyo, Japan), media in the flasks were removed by serological pipette. Both cell types were washed with $5.0 \mathrm{~mL}$ of cold, sterile PBS (GE Healthcare, Chicago, IL, USA) twice. After the last wash with PBS, cells were trypsinized by adding $5.0 \mathrm{~mL}$ of trypsin (GE Healthcare, Chicago IL, USA) and incubated for ten minutes at room temperature to allow for adhered cells to detach from the bottom of the flask. After the ten minute incubation, the flasks of cells were taken to a phase-contrast microscope (Olympus ${ }^{\circledR}$, Shinjuku, Tokyo, Japan) to confirm that the cells have been successfully trypsinized. The trypsin was then neutralized with the addition of HFF-1 media (Dulbecco's Modified Eagle Media $+15 \%$ Fetal Bovine Serum) and Melanoma media (Dulbecco's Modified Eagle Media $+10 \%$ Fetal Bovine Serum) for the HFF-1 and COLO-829 cells, respectively. The HFF-1 and COLO-829 cells were transferred into separate $15.0 \mathrm{~mL}$ conical centrifuge tubes (Fisherbrand, Waltham, MA, USA) and centrifuged at $200 \mathrm{rpm}$ for five minutes in an Eppendorf Centrifuge 5804R-15AMP (Eppendorf AG, Hamburg, Germany). The supernatant in the conical tubes was aspirated out and the pellets of HFF-1 and COLO-829 cells were then resuspended in $1.0 \mathrm{~mL}$ of their respective media. Next, $20 \mu \mathrm{L}$ from each of the cell stocks were pipetted onto a cellometer cell counting chamber (Nexcelom Bioscience, Lawrence, MA, USA) to obtain the live cell concentrations of both cell stocks with the Cellometer Auto T4 (Nexcelom Bioscience, Lawrence, MA, USA). Cell proliferation assays on $2 \mathrm{D}$ matrices were performed with varying concentrations of stevioside, sucralose, and sucrose.

\section{HFF-I and COLO-829 cell analysis}

To observe the initial rate of cellular adhesion during the first time point and calculate the rate of cell proliferation for the remaining time points, all populations of HFF-1 and COLO-829 cells were marked with the fluorescein dye, calcein (Life Technologies, Carlsbad, CA, USA) as described previously. ${ }^{15}$ The calcein solution was prepared with a concentration of $1.0 \mathrm{uL}$ calcein per $1.0 \mathrm{~mL}$ of PBS. Plates were removed from the incubator at the corresponding time points and washed twice with $0.5 \mathrm{~mL}$ of PBS; once the wash steps were completed, $0.2 \mathrm{~mL}$ of the calcein solution was aliquoted into all wells in the absence of light. The plates were incubated in a dark chamber for fifteen minutes, allowing the cells to bind the calcein. After the incubation period was over, the plate was transferred to a Filtermax F5 Microplate Reader (Molecular Devices, San Jose, CA, USA), where the number of cells in each well were analyzed. Once the data had been acquired for all of the plates, the plates were then transferred to a fluorescent microscope (Olympus ${ }^{\circledR}$, Shinjuku, Tokyo, Japan), where direct images of the fluorescing cells were captured.

\section{FACS analysis}

As described by Eckhart, Vaghasia, Kniseley, Bucci, \& Tawil, 
HFF-1 and COLO-829 cultured cells were prepared separately in 75 $\mathrm{cm}$ vented flasks. Once confluency of the cells has been confirmed via phase-contrast microscopy, media in the flasks was removed by serological pipette. Both cell types were washed with $5.0 \mathrm{~mL}$ of cold, sterile PBS twice. After the last wash with PBS, cells were trypsinized by adding $5.0 \mathrm{~mL}$ of trypsin and incubated for ten minutes at room temperature to allow for adhered cells to detach from the bottom of the flask. After the ten minute incubation, the flasks of cells were taken to a phase-contrast microscope to confirm that the cells have been successfully trypsinized. The HFF-1 and COLO-829 cells were then transferred to separate $15.0 \mathrm{~mL}$ conical centrifuge tubes to be centrifuged at $200 \mathrm{rpm}$ for five minutes. The supernatant in the conical tubes was aspirated out and the pellets of HFF-1 and COLO-829 cells were then resuspended in $1.0 \mathrm{~mL}$ of sterile PBS. Next, $20 \mu \mathrm{L}$ from each of the cell stocks were pipetted onto a cellometer cell counting chamber to obtain the live cell concentrations of both cell stocks with the Cellometer Auto T4. Calculations were done to figure out the volume of resuspended cells needed for each well to contain 100,000 live cells. Three replicates of each sugar concentration for each cell type was prepared, for each replicate would receive either $5_{5}, \beta_{1}$, or no antibodies. Once the volume has been calculated, the cells were then transferred into microcentrifuge tubes where the total volume was normalized to $100 \mu \mathrm{L}$ with PBS. Next, the $\alpha_{5} \& \beta_{1}$ antibodies were separately added in volumes of $2.5 \mu \mathrm{L}$ to the microcentrifuge tubes once added, the cells were incubated for one hour in a $5^{\circ} \mathrm{C}$ chamber. After the incubation period is over, cells were washed with cold PBS twice, vortexed thoroughly, and analyzed with the Guava easyCyte ${ }^{\mathrm{TM}}$ system and software program. HFF-1 and COLO-827 cells were cultured for one week in the varying sweetener concentrations in a 24-well cluster, as aforementioned in the HFF-1 and COLO-829 Cell culture. After the 7-day incubation period was over, the cells were transferred to a microcentrifuge, where the cells were subjected to two washes with PBS and the addition of the $\alpha_{5}$ and $\beta_{1}$ antibodies. The cells were then analyzed on the Guava easyCyte ${ }^{\mathrm{TM}}$ system.

\section{Statistical analysis}

Statistical analysis was conducted by producing descriptive statistics, mean and standard deviation, for all measurements taken. Significance was determined by performing a Paired Student's T-Test between samples of different treatments. Statistical significance was assigned to any samples with a p-value $<0.05$.

\section{Results}

\section{The effect of collagen and fibronectin on healthy cells}

First, a screen of different scaffold types and concentrations was run to determine the best scaffold for further experimentation. The scaffolds tested during this experiment were $5 \mu \mathrm{g} / \mathrm{mL}$ and $10 \mu \mathrm{g} /$ $\mathrm{mL}$ concentrations of both collagen and fibronectin-coated on three 24-well cell culture clusters. Each well was seeded with $1 \times 10^{4}$ healthy cells and incubated at $37^{\circ} \mathrm{C}$ for 1 hour, 3 days, and 7 days respectively. Cellular proliferation and initial adhesion data were collected to determine the scaffold with which healthy cells exhibited the most favorable proliferation characteristics. Cellular adhesion was observed by comparing the number of attached cells in the plates 1 hour after initial seeding. Proliferation was observed over the next 7 days by taking periodic measurements which were standardized to the initial adhesion data to produce percent proliferation data.

No significant differences were observed in terms of initial cell adhesion between collagen and fibronectin after 1 hour of incubation (Figure 1A). Percent cell proliferation after 4 days of incubation was similar for all conditions, with all conditions showing an

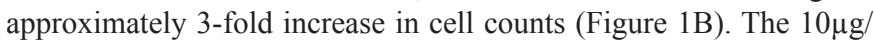
$\mathrm{mL}$ fibronectin coating exhibited a slight increase at the 4-day mark, but this increase was not significant $(\mathrm{p}>0.05)$ (Figure 1B). The day 7 proliferation for both $5 \mu \mathrm{g} / \mathrm{mL}$ and $10 \mu \mathrm{g} / \mathrm{mL}$ collagen scaffolds appears to be greater than that of fibronectin, exhibiting a statistically significant $(\mathrm{p}<0.05) 2$-fold increase in cell proliferation versus the $5 \mu \mathrm{g} / \mathrm{mL}$ fibronectin condition (Figure 1B). There was not a statistically significant difference between $5 \mu \mathrm{g} / \mathrm{mL}$ and $10 \mu \mathrm{g} / \mathrm{mL}$ fibronectin conditions, nor was there a difference between the $5 \mu \mathrm{g} / \mathrm{mL}$ and $10 \mu \mathrm{g} / \mathrm{mL}$ collagen conditions after 7 days (Figure 1B). There was no notable difference in cell morphologies between the healthy cells grown on either collagen or fibronectin scaffolds, with both scaffold types giving rise to spindle-like cells of approximately the same size and shape (Figure 1C). In conclusion, we found that the collagen scaffolds at any concentration exhibited increased cell proliferation after 7 days of culturing than the $5 \mu \mathrm{g} / \mathrm{mL}$ fibronectin scaffold. Given this information, the $10 \mu \mathrm{g} / \mathrm{mL}$ collagen scaffold was chosen for further experimentation.

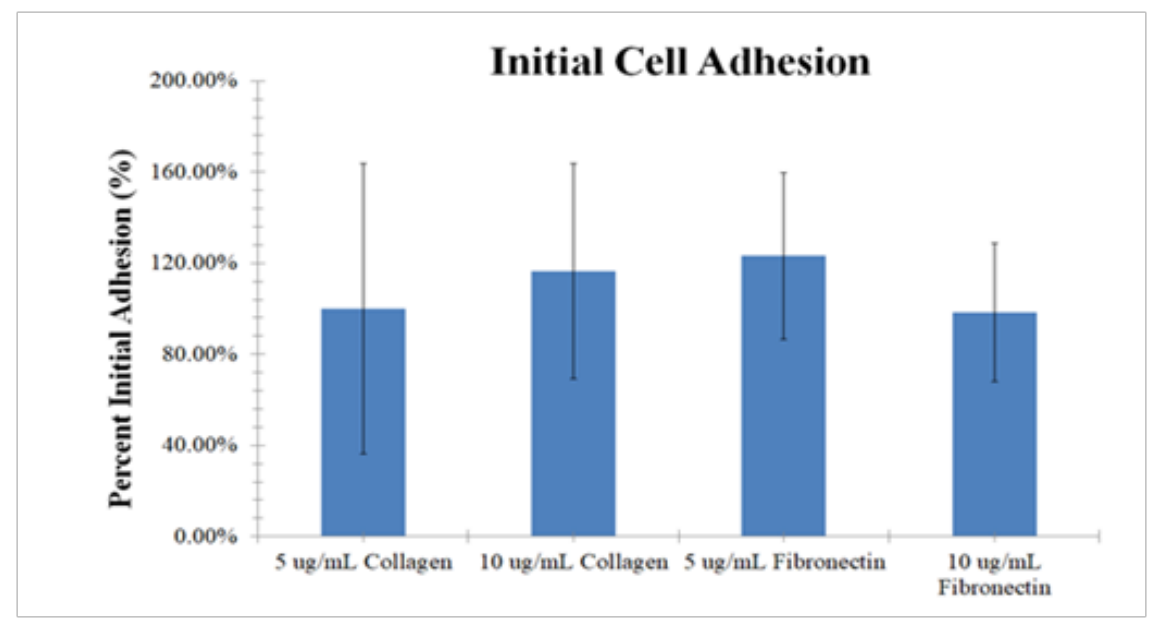




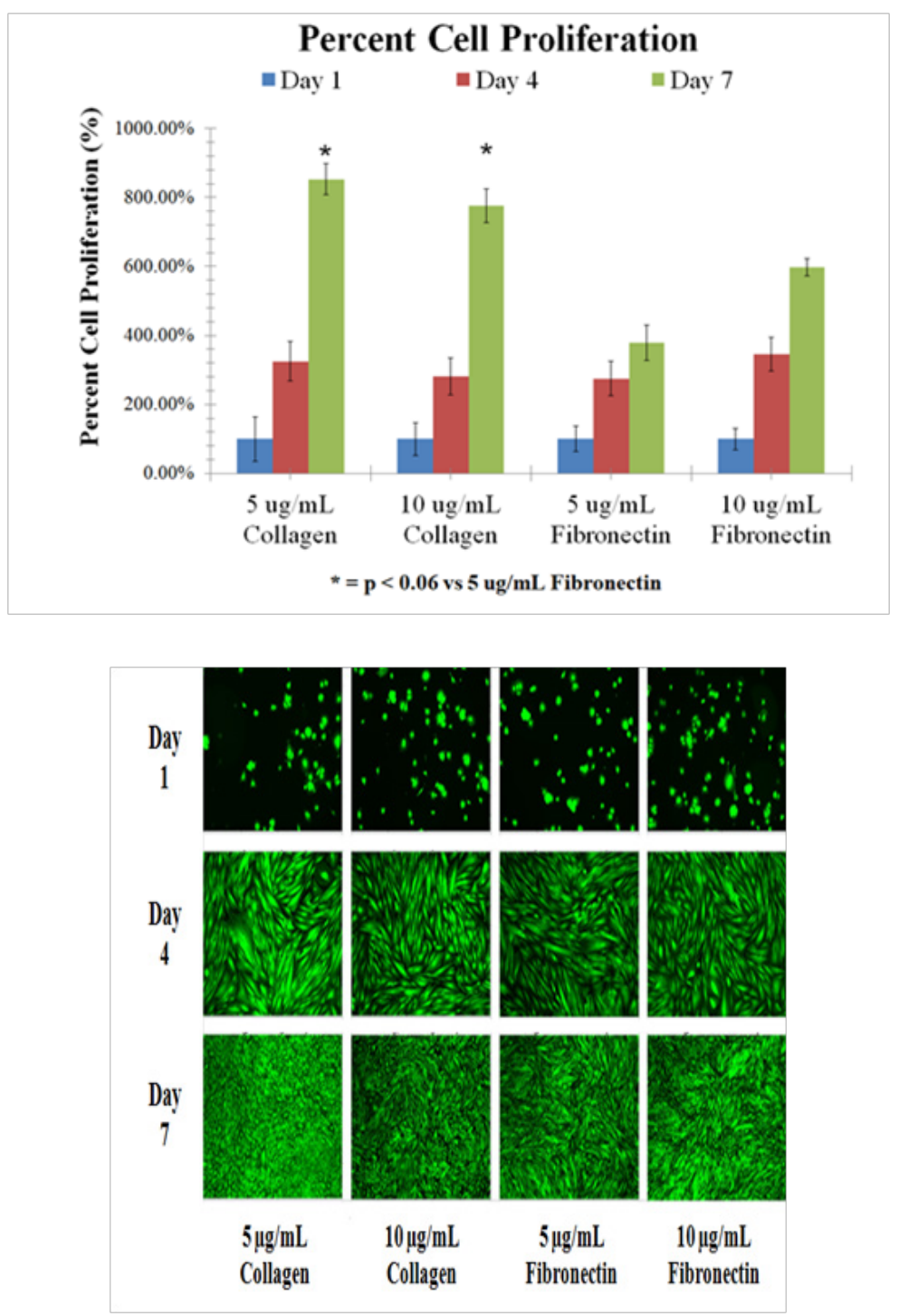

Figure I The effect of fibronectin and collagen on HFF-I cells (A) Initial percent adhesion of healthy cells grown on varying concentration collagen and fibronectin. There are no significant differences found between the 4 conditions. (B) Proliferation of healthy cells grown on varying concentration collagen and fibronectin. Collagen shows greater proliferation rate than fibronectin $5 \mathrm{ug} / \mathrm{mL}$ at $\mathrm{p}<0.06$. (C) Morphology of healthy cells grown on collagen and fibronectin over 7 days. Cells appear healthy and spindle-like and reach full confluence by day 7.

\section{The effect of sweeteners on the behavior of healthy \& cancerous cells}

\section{Healthy cells}

After scaffold selection and baseline, healthy cell characteristics were determined, an experiment was undertaken to determine the effect of non-nutritive sweeteners on the behavior of healthy cells. This first study served to establish a baseline of the effects of these substances on normal, healthy cells and to narrow the range of NNS concentrations for later experimentation. In this experiment, we seeded 10,000 healthy cells onto a $10 \mu \mathrm{g} / \mathrm{mL}$ collagen-coated cell culture cluster in the presence of increasing concentrations of stevioside, sucralose, and sucrose. After 1 hour, 3 days, and 7 days of culture, the plates were removed from incubation and treated with calcein-AM before fluorescence data was collected by Plate Reader and fluorescence microscopy.
The initial cell adhesion trends observed indicate that there is a 2 to 3 -fold reduction in initial cellular adhesion at $10 \mathrm{mg} / \mathrm{mL}$ and $20 \mathrm{mg} /$ $\mathrm{mL}$ concentrations of stevioside compared to no sweetener controls, whereas sucralose and sucrose seemed to have no observable effect on initial adhesion when compared to the no sweetener control (Figure 2A). Stevioside treated cells at concentrations of more than $10 \mathrm{mg} / \mathrm{mL}$ also exhibited at least 2-fold lower initial cell adhesion compared to all concentrations of sucralose and all concentrations of sucrose (Figure 2A). After 4 days of cell culture, there was a noticeable increase in the number of cells in the stevioside treated media compared to other days 4 measurements, with an approximately $150 \%$ increase compared to the no sweetener control and a $>200 \%$ increase compared to all sucralose concentrations (Figure 2B). The $10 \mathrm{mg} / \mathrm{mL}$ stevioside treated cells exhibited approximately a $200 \%$ increase compared to all concentrations of sucrose treated cells (Figure 2B). The sucralose treated cells, in contrast, exhibited decreases in day 4 proliferation percentages compared to sucrose and no sweetener controls, with 
a $>2$-fold decrease compared to no sweetener controls (Figure 2B). The cellular proliferation data indicates a significant increase in cell growth at day 7 for stevioside when compared to sucralose (Figure 2B). Besides, the $20 \mathrm{mg} / \mathrm{mL}$ concentration of either NNS had a deleterious effect on cell survival (Figure 2B). The data indicates that there is an almost 3-fold increase in the 7-day cell proliferation when treated with stevioside at $10 \mathrm{mg} / \mathrm{mL}$ compared to no sweetener controls, whereas sucralose inhibits cell growth at all concentrations. Sucrose at concentrations of $10 \mathrm{mg} / \mathrm{mL}$ seemed to have a small effect on overall cell proliferation when compared to $0 \mathrm{mg} / \mathrm{mL}$ controls, but overall sucrose had little effect on cell proliferation (Figure 2B). Closer observation of the day 7 dataset reveals enhanced growth at $10 \mathrm{mg} /$ $\mathrm{mL}$ of stevioside $(\mathrm{p}<0.05)$ and $5 \mathrm{mg} / \mathrm{mL}$ stevioside $(\mathrm{p}<0.05)$ compared to controls (Figure 2B). Sucrose, while seemingly inducing a small pro-proliferative effect on cells at concentrations $>20 \mathrm{mg} / \mathrm{mL}$, did not approach statistical significance $(\mathrm{p}>0.05)$ (Figure 2B). Sucralose had, as observed before, a negative effect on cell proliferation that was more marked with increasing concentrations of the NNS (Figure 2B). Finally, cell morphology was observed in to determine if the NNS affected cell appearance under fluorescence microscopy (Figure 2C). Cell morphology is normal in the absence of sweeteners, exhibiting spindle formation and approaching full confluence by the end of day 7 (Figure 2C). At higher concentrations, extreme changes in cell morphology are observed, with long spindle formation and loss of confluency in most conditions over $5 \mathrm{mg} / \mathrm{mL}$ for sucralose and $10 \mathrm{mg} /$ $\mathrm{mL}$ for stevioside (Figure 2C). In contrast to NNS conditions, sucrose at any concentration did not seem to affect cell morphology, even at $20 \mathrm{mg} / \mathrm{mL}$ concentrations (Figure 2C).

In conclusion, sucrose was observed to have no significant effects on cell proliferation or adhesion after 1 hour, 4 days, or 7 days. In contrast, sucralose treated cells, while displaying no significant change in initial adhesion, demonstrated a marked decrease in cell proliferation at 4 days. This decrease was increased further after 7 days of cell culture. Finally, stevioside demonstrated an increase in the proliferation of healthy cells at both 4 and 7 days of cell culture, but this increase was negated at concentrations exceeding $>10 \mathrm{mg} / \mathrm{mL}$. Stevioside also was the only substance that produced a demonstrable decrease in the initial cell adhesion, a decrease that was inversely proportional to stevioside concentration. High concentrations of both stevioside and sucralose caused extreme changes in cell morphology, including loss of confluency and aberrant cell shape.
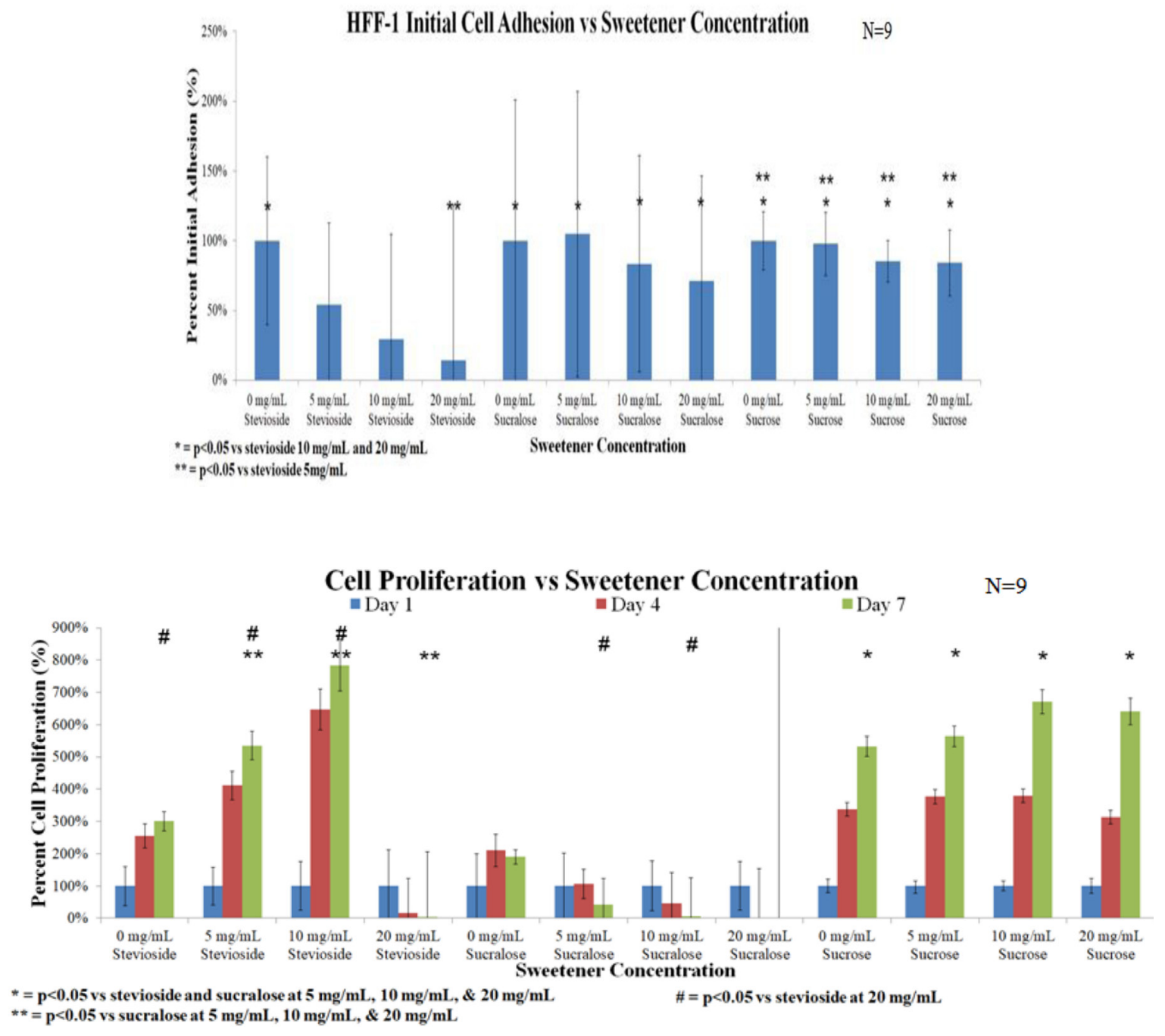

Citation: Kircher E, Lee J,Wang HC et al.The effect of natural sugar and sweeteners on normal and cancerous human fibroblasts.J Appl Biotechnol Bioeng. 2019;6(5):210-221.DOI: 10.15406/jabb.2019.06.00194 


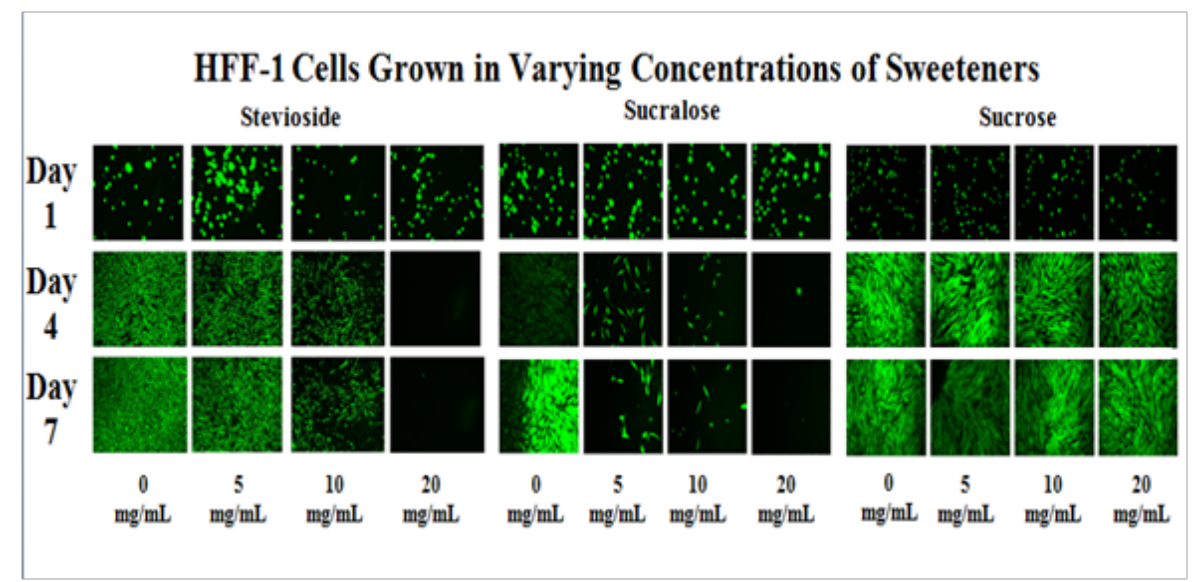

Figure 2 The Effect of NNS on HFF-I Cells (A) Initial cell adhesion of HFF cells in media spiked with increasing concentrations of the sweeteners stevioside, sucralose, and sucrose. Sucralose at all concentrations shows greater initial cell adhesion than stevioside $10 \mathrm{mg} / \mathrm{mL}$ and $20 \mathrm{mg} / \mathrm{mL}$. Sucrose at all concentrations shows greater initial cell adhesion than stevioside $5 \mathrm{mg} / \mathrm{mL}, 10 \mathrm{mg} / \mathrm{mL}$, and $20 \mathrm{mg} / \mathrm{mL}$. Stevioside $0 \mathrm{mg} / \mathrm{mL}$ has greater initial cell adhesion than stevioside $5 \mathrm{mg} / \mathrm{mL}$, and stevioside $20 \mathrm{mg} / \mathrm{mL}$ has less initial cell adhesion than stevioside $10 \mathrm{mg} / \mathrm{mL}$. (B) Cell proliferation over 7 days in media spiked with increasing concentrations of the sweeteners stevioside, sucralose, and sucrose. Stevioside induces greater cell proliferation than other coatings at $10 \mathrm{mg} / \mathrm{mL}$, but induces cell death at $20 \mathrm{mg} / \mathrm{mL}$. Sucralose shows cytotoxic effects at all concentrations, and sucrose has no significant effect on cellular behavior at all concentrations ( $<<0.05)$. (C) Morphology of HFFI cells grown on $10 \mathrm{ug} / \mathrm{mL}$ collagen with stevioside, sucralose, and sucrose mixed in media. Cell death is observed at NNS of concentrations of $20 \mathrm{mg} / \mathrm{mL}$ or greater, whereas aberrant morphology and long spindle formation is observed at concentrations of $5 \mathrm{mg} / \mathrm{mL}$ and I $0 \mathrm{mg} / \mathrm{mL}$. Sucrose has no effect on cell morphology at any concentration.

\section{Healthy \& cancerous cells}

Cell proliferation analysis was also performed on healthy and cancerous cells in tandem grown on a narrower sweetener concentration range than the first experiment. The second experiment was conducted similarly to the first, evaluating the initial adhesion 1 hour after seeding and percent proliferation after 3 days and 7 days of culture. At each time point, cells were treated with calcein before being measured using a Plate Reader and fluorescence microscopy.

Initial cell adhesion data indicates that there was a significant decrease $(\mathrm{p}<0.05)$ in the initial adhesion of healthy fibroblasts when grown in the presence of stevioside (Figure 3A). This decrease was not seen for cells grown in the presence of sucralose (Figure $3 \mathrm{~A}$ ). There was a significant decrease in the initial adhesion of healthy cells grown in $15 \mathrm{mg} / \mathrm{mL}$ stevioside versus those grown in $5 \mathrm{mg} /$ $\mathrm{mL}$ stevioside $(\mathrm{p}<0.05)$ (Figure $3 \mathrm{~A})$. Cells grown in the presence of sucralose demonstrated significantly greater initial adhesion compared to those grown in stevioside $(\mathrm{p}<0.05)$ (Figure $3 \mathrm{~A})$. The cancerous fibroblasts exhibited the opposite effect, stevioside elicited the greater initial adhesion compared to sucralose, but both sweeteners markedly increased initial adhesion compared to no sweetener controls $(\mathrm{p}<0.05)$ (Figure 3B). The same was seen for sucrose, which allowed for greater initial adhesion of the cancerous cells (Figure 3B). In terms of proliferation, all conditions demonstrated some level of increase in cell proliferation at day 4 compared to day 1 (Figure 3C). For healthy fibroblasts, the greatest initial increase in proliferation between day 1 and day 4 timepoints occurred in the $5 \mathrm{mg} / \mathrm{mL}$ stevioside treated cells, with a 8 -fold increase, whereas the $15 \mathrm{mg} / \mathrm{mL}$ stevioside and all sucralose conditions demonstrated only a 2 -fold increase in proliferation over the same time period (Figure 3C). Stevioside at $5 \mathrm{mg} / \mathrm{mL}$ elicited a 1.5 -fold greater day 7 proliferation than the no sweetener control and $10 \mathrm{mg} / \mathrm{mL}$ sucrose conditions, whereas $10 \mathrm{mg} /$ $\mathrm{mL}$ stevioside and $15 \mathrm{mg} / \mathrm{mL}$ stevioside gradually induced lesser proliferation with increasing concentrations (Figure 3C). Stevioside at $15 \mathrm{mg} / \mathrm{mL}$ exhibited similar day 7 proliferation rates to $5 \mathrm{mg} / \mathrm{mL}$ sucralose treated cells (Figure 3C). Overall, sucralose reduced cell proliferation of healthy cells at any concentration, though the effect was greatest at $5 \mathrm{mg} / \mathrm{mL}$ (Figure 3C). For cancerous cells, there is a marked decrease in all proliferation rates after treatment with any concentration of sweetener, of any identity (Figure 3D). Compared to the no sweetener control, which exhibited a 122-fold increase from day 1 to day 4, sweetener treated cells only exhibited a 54-fold increase for $5 \mathrm{mg} / \mathrm{mL}$ stevioside, a 26 -fold increase for $10 \mathrm{mg} / \mathrm{mL}$ stevioside, and an 8 -fold increase for $15 \mathrm{mg} / \mathrm{mL}$ stevioside (Figure $3 \mathrm{D})$. A similar effect is seen for sucralose, where cells exhibited a 40 -fold increase from day 1 to day 4 for $1 \mathrm{mg} / \mathrm{mL}$ sucralose, a 20 -fold increase for $2.5 \mathrm{mg} / \mathrm{mL}$ sucralose, and a 17 -fold increase for $5 \mathrm{mg} / \mathrm{mL}$ sucralose (Figure 3D). Day 7 proliferation rates demonstrated similar phenomena, with stevioside having a more significant effect on cell proliferation compared to the no sweetener control than sucralose (Figure 3D). Additionally, $15 \mathrm{mg} / \mathrm{mL}$ stevioside cause almost all of the cells in the culture to die off after 7 days (Figure 3D).

Fluorescent microscopy shows that healthy cells grown in the presence of sweetener show marked the loss of confluency, less spindle formation, and lower cell numbers that became more marked with increasing concentrations of sweeteners (Figures 3E \& 3F). These observations were consistent regardless of whether sucralose or stevioside was used. Similar effects were observed for cancerous cells, with increases in sweetener concentration leading to lower cell growth and a greater number of spherical cells in the culture, even after 7 days (Figures $3 \mathrm{G} \& 3 \mathrm{H}$ ). The effects were less marked on cancer cells than in healthy cells, as they typically demonstrate less spindle formation and do not grow to confluence over this time frame as healthy fibroblasts do.

The healthy and cancerous cells grown in the sweeteners studied here demonstrated opposite adhesion behavior depending on the type of sweetener they were grown in. Stevioside elicited a significant decrease in initial cell adhesion for healthy cells, whereas both stevioside and sucralose caused an increase in initial adhesion of cancerous cells compared to no sweetener controls. The cancer cells exhibited greater initial adhesion in the presence of stevioside 
than in sucralose. Similar results were seen for the sweeteners when used on healthy and cancerous cells in terms of proliferation. In this experiment, the same notable reduction in cell proliferation was noted for sucralose for both healthy and cancerous cells. The effect was more marked with cancerous cells, as they proliferated rapidly in the absence of the sweeteners, but were stymied in its presence. Similarly, the addition of $5 \mathrm{mg} / \mathrm{mL}$ stevioside to the cells caused a rapid increase $(\sim 1.5$-fold $)$ in proliferation for the healthy cells but caused a large decline $(>13$-fold) in proliferation for cancerous cells.

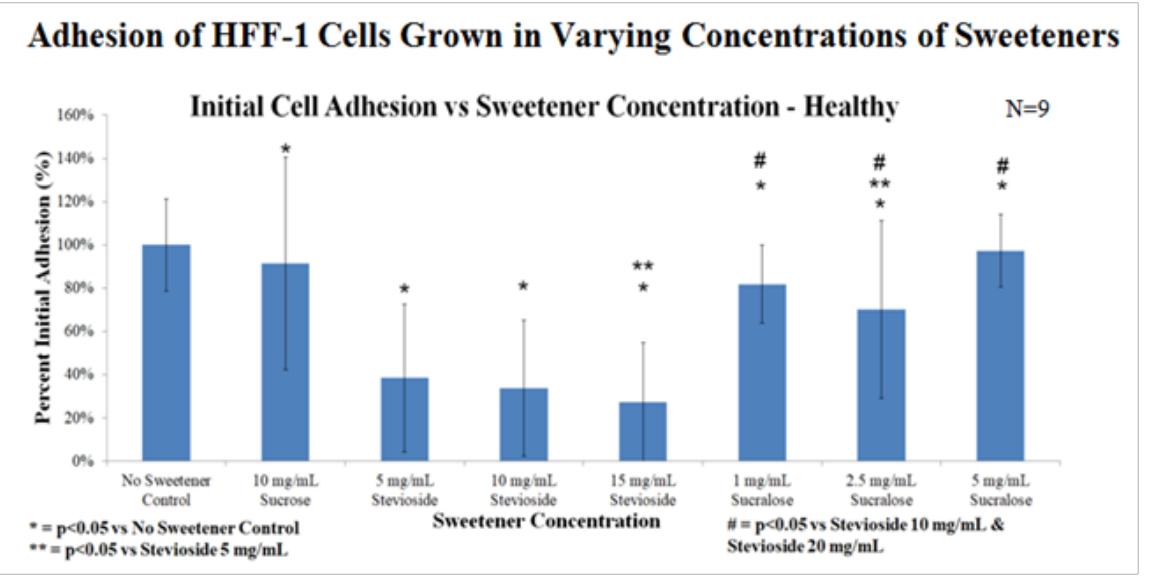

Adhesion of COLO-829 Cells Grown in Varying Concentrations of Sweeteners
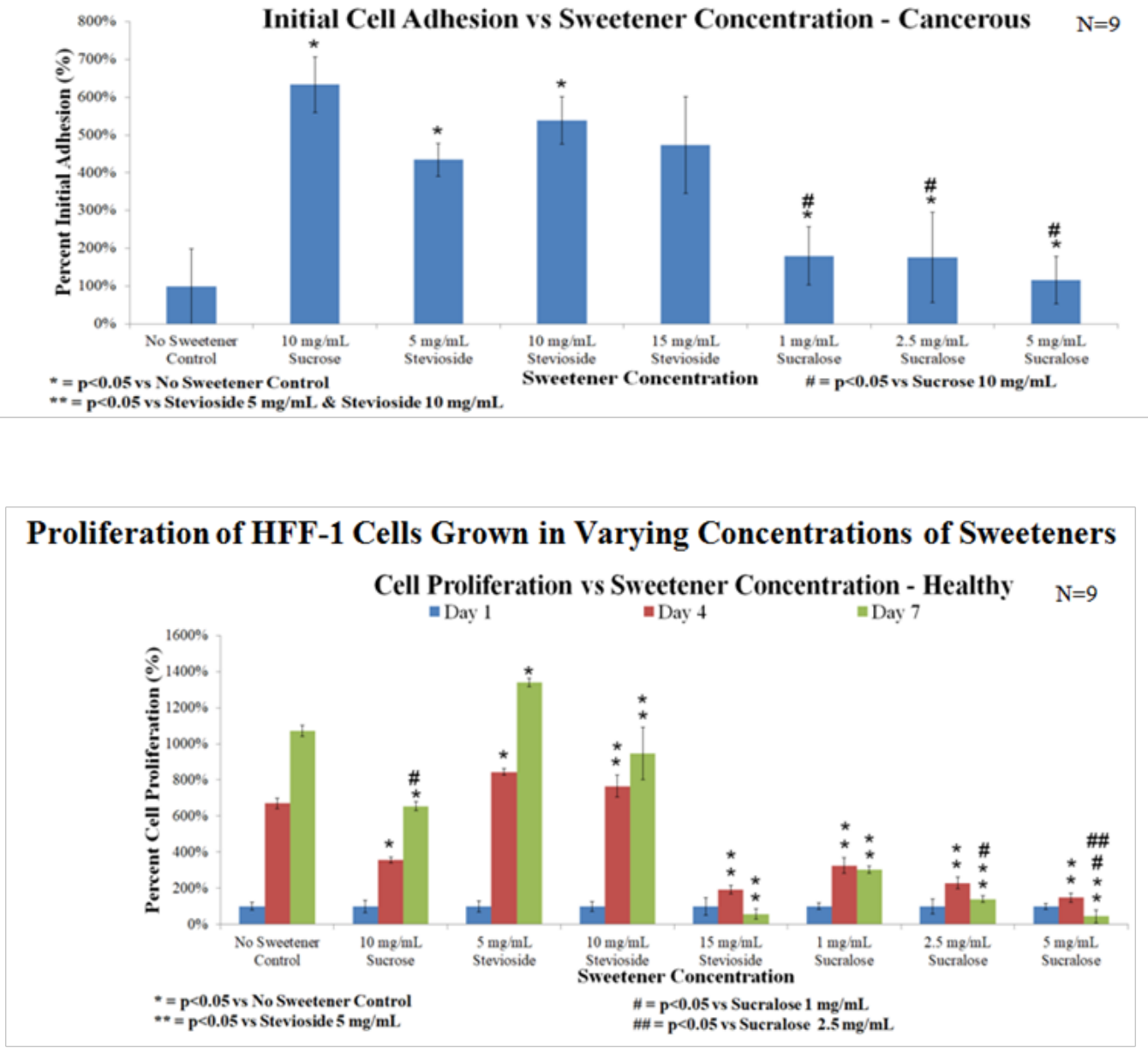
Proliferation of COLO-829 Cells Grown in Varying Concentrations of Sweeteners
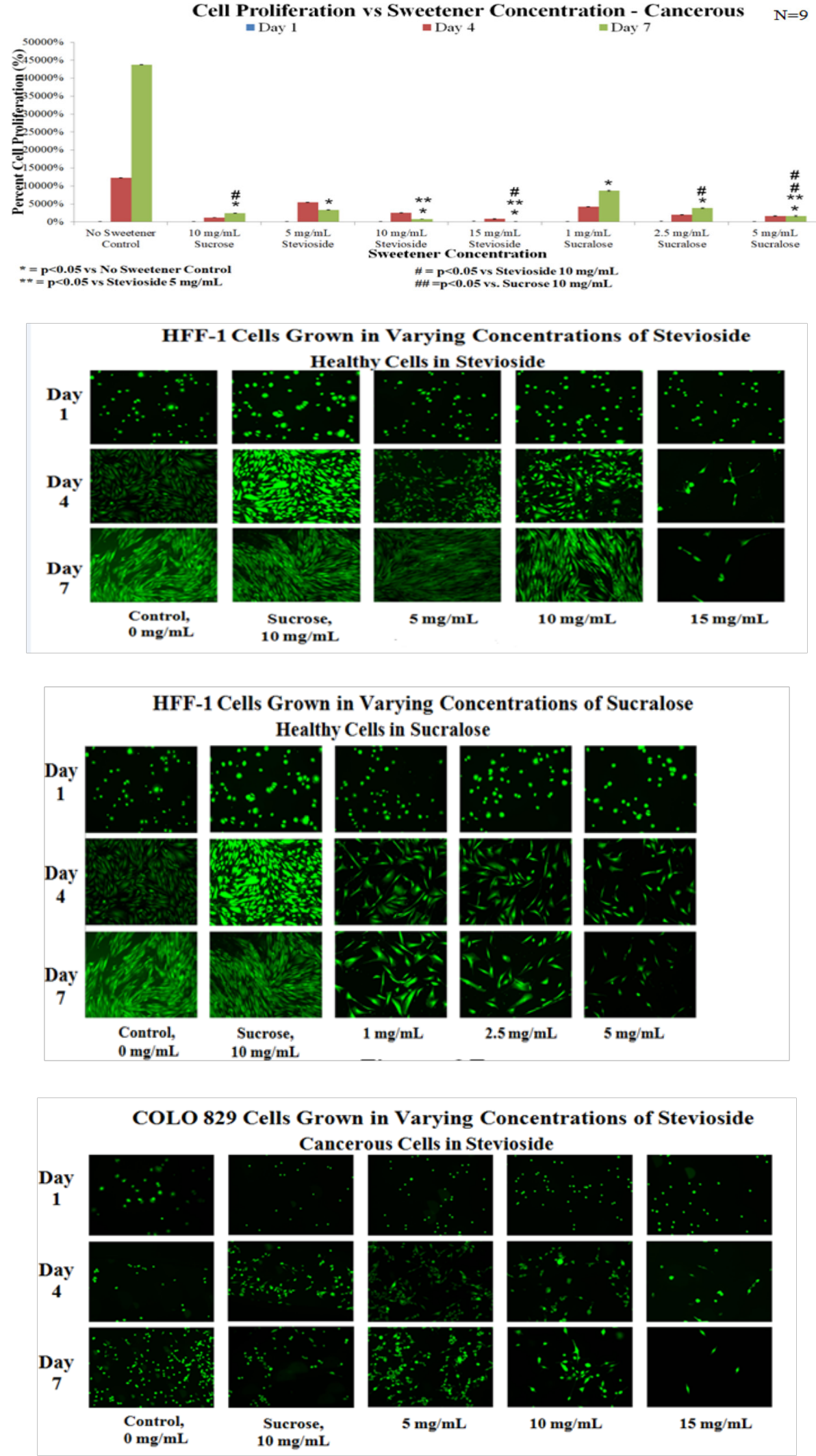


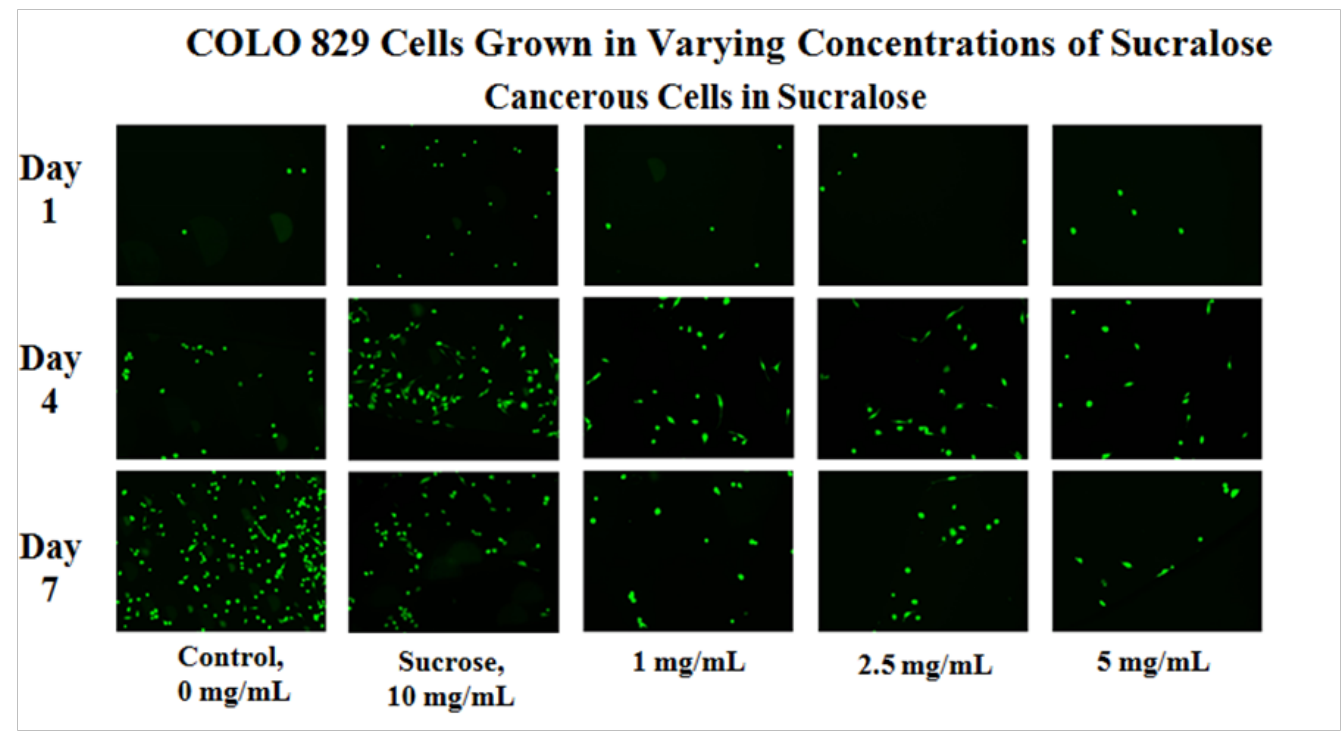

Figure 3 The Effect of NNS on Healthy and Cancerous Cells (A) The initial cell adhesion of healthy cells in the presence of increasing concentrations of stevioside and sucralose. Stevioside treated cells demonstrate a reduction in initial cell adhesion by about 2-fold when compared to sucrose and no sweetener controls. Sucralose had no significant effects on initial cell adhesion compared to no sweetener controls. (B) The initial cell adhesion of COLO-829 cells in the presence of increasing concentrations of stevioside and sucralose. Sucrose and stevioside treated cells demonstrated a $>4-f o l d$ increase in initial adhesion, whereas sucralose treated cells showed a $\sim 1.5$-fold increase in initial adhesion. (C) Percent cell proliferation of healthy cells grown in increasing concentrations of stevioside and sucralose. Stevioside elicited an $\sim 1.5$-fold increase in day 7 cell proliferation at concentrations of $5 \mathrm{mg} / \mathrm{mL}$, and a decrease in proliferation at concentrations of $15 \mathrm{mg} / \mathrm{mL}$. Sucralose at all concentrations drastically reduced the proliferation of the cells at 4 days and 7 days. (D) Percent cell proliferation of COLO-829 cells in the presence of increasing concentrations of stevioside and sucralose. All sweetener treated cells demonstrated drastic reductions in the overall cell proliferation at 4 and 7 days. Stevioside at any concentration reduced cell proliferation, but was especially potent at 15 mg/mL. Sucralose treated cells proliferated more than stevioside treated cells overall, but significant reductions were still seen compared to no sweetener controls. (E) Healthy cells grown in increasing concentrations of stevioside. At concentrations $>15 \mathrm{mg} / \mathrm{mL}$, stevioside treated cells demonstrated drastic changes in morphology and loss of traditional spindle shape seen in other cultures. (F) Healthy cells grown in increasing concentrations of sucralose. At any concentration, loss of confluency and changes in morphology are seen, especially at concentrations of $5 \mathrm{mg} / \mathrm{mL}$. (G) COLO-829 cells grown in increasing concentrations of stevioside. As concentration of sweetener increases, total cell numbers are reduced and lose some of their spindle formation. (H) COLO-829 cells grown in increasing concentrations of sucralose. As concentration of sweetener increases, total cell numbers are reduced and less spindle formation is observed.

\section{The effect of NNS on integrin expression in healthy and cancerous cells}

In addition to cell proliferation assays, FACS analysis was performed on cells treated with sweetener to examine the effect of each sweetener on integrin expression. In short, cells grown in the presence of sweetener for 7 days were incubated with anti- $a_{5}$ and anti- $\beta_{1}$ fluorescent antibodies for one hour before cell sorting by FACS to quantify the fluorescence of labeled cells. The conditions tested included $2 . \mathrm{mg} / \mathrm{mL}$ sucralose, $10 \mathrm{mg} / \mathrm{mL}$ stevioside, and $2.5 \mathrm{mg} /$ $\mathrm{mL}$ sucralose. Increased fluorescence indicated higher integrin expression, and each sweetener condition was compared to both day 1 and no sweetener controls to identify changes in integrin expression.

Examination of the $a_{5}$ integrin expression of healthy fibroblasts treated with sucrose, sucralose, and stevioside in Figure 4A show that sucralose caused a slight increase in $a_{5}$ integrin expression compared to no sweetener controls. Meanwhile, stevioside treated cells exhibited almost no change in $a_{5}$ integrin expression, and sucrose treated cells displayed slight decreases in $a_{5}$ integrin expression (Figure 4A). Sucralose and stevioside caused a slight increase in $\beta_{1}$ integrin expression in healthy cells, while sucrose exhibited a slight decrease in $\beta_{1}$ expression (Figure 4A). The same analysis was performed for cancerous cells, and it was observed that $a_{5}$ integrin expression was almost completely lost in the presence of all three sweeteners when compared to no sweetener controls (Figure 4B). Similar results were seen for $\beta_{1}$ integrin expression in cancer cells, with almost no expression of $\beta$ integrins after 7 days of treatment in all sweeteners when compared to no sweetener controls (Figure 4B). Finally, the integrin expression of healthy and cancerous cells in each sweetener was compared to determine the different levels of expression between the cell lines (Figure 4C). For controls grown in the absence of sweeteners, there was much greater $a_{5}$ and $\beta_{1}$ integrin expression in healthy cells than there was for cancerous cells (Figure 4C). This effect was also observed for all sweetener treated cells, though to a much greater degree, as integrin expression was almost completely lost in sweetener treated cancer cells, but relatively unchanged in healthy cells (Figure 4C).

Healthy cells grown in sucrose and stevioside over 7 days showed an increase in $a_{5}$ expression and decrease in $\beta_{1}$ expression. Healthy cells grown in sucralose over 7 days showed the least increase in $a_{5}$ expression and least $\beta_{1}$ expression. The cancerous cell $a_{5}$ integrin expression in Figure 4A shows an extreme decrease of $a_{5}$ expression in all three sweeteners. The cancer cell $\beta_{1}$ integrin expression exhibit an extreme decrease of $\beta_{1}$ expression in all three sweeteners, while the control displayed relatively small integrin expression compared to healthy cells. Cancer cells grown in all sweeteners showed great decreases in $a_{5}$ and $\beta_{1}$ expression, and sucrose had the highest, albeit small, $\beta_{1}$ expression among the sweeteners. 


\section{Integrin Expression of HFF Cells}

a5

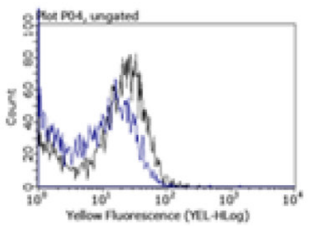

ß1

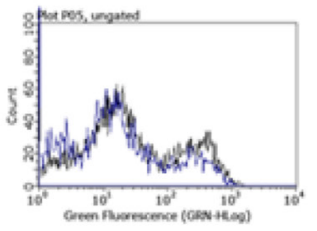

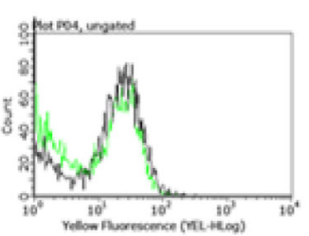

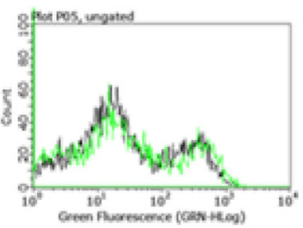

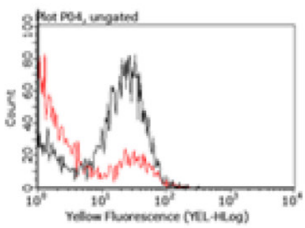

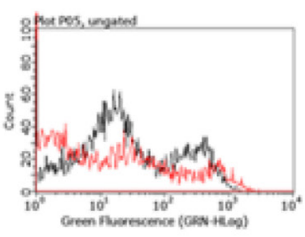

Control

Sucrose

Stevioside

Sucralose

\section{Integrin Expression of HFF Cells}
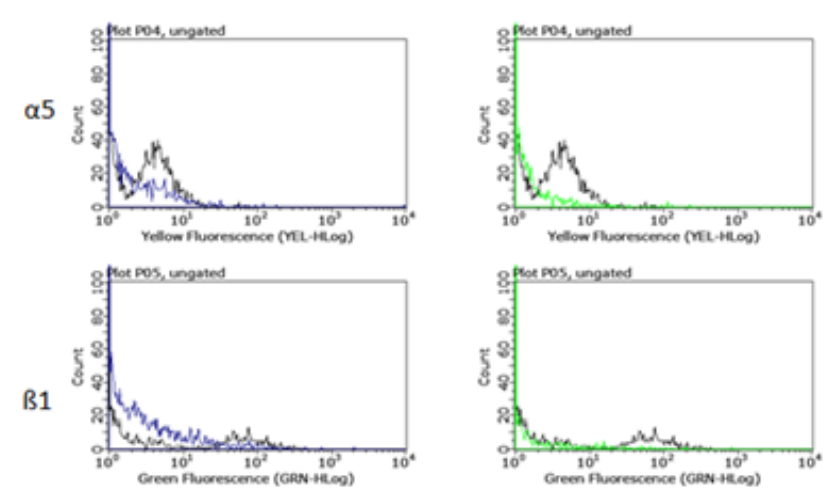

B1

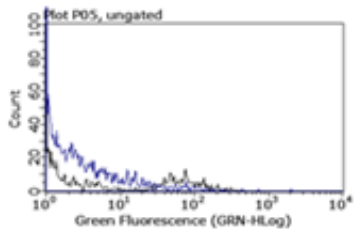

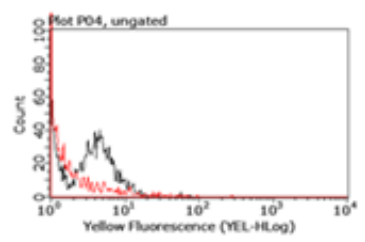

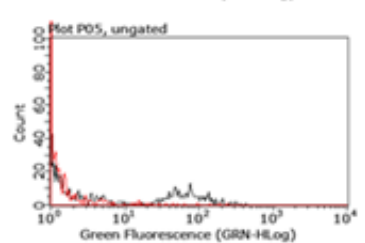

Control

Sucrose

Stevioside -

Sucralose —

\section{Integrin Expression of HFF and COLO Cells Day 7}

Control
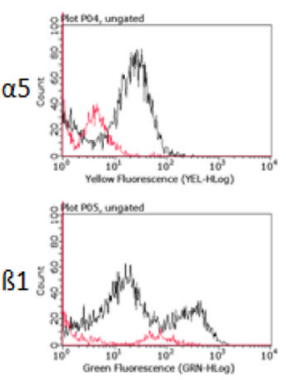

Sucrose
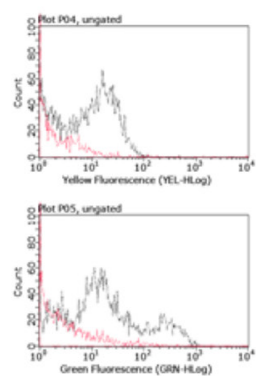

Stevioside
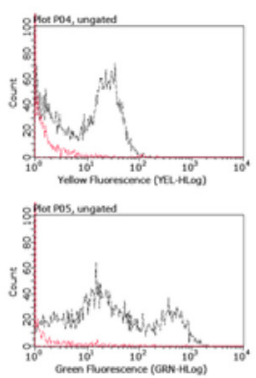

Sucralose
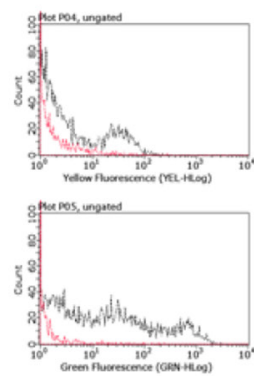

Healthy

Cancerous

Figure 4 FACS Analysis of Integrin Expression of Healthy and Cancerous Cells in the Presence of NNS (A) The expression of a5 and 5 I integrins was monitored over 7 days in healthy cells grown in the presence of sucrose, sucralose, and stevioside. Healthy cells grown in sucralose had the smallest increase in a5 expression and greatest decrease in 51 expression relative to the control, sucrose, and stevioside. (B) COLO-827 cells grown in sucrose, sucralose, and stevioside showed great decreases in $\mathrm{a} 5$ and $5 \mathrm{I}$ expression, but sucrose had the highest, albeit small, $5 \mathrm{I}$ expression among the sweeteners. (C) Comparison of integrin expression between healthy and COLO-827 cells grown in sucrose, sucralose, and stevioside over 7 days. Healthy cells exhibited higher overall levels of expression of integrins in all conditions than cancer cells, including controls that were not exposed to sweeteners. 


\section{Discussion}

In this study, we first examined the effect of scaffold type on the growth behavior of healthy cells and found that collagen affected greater overall cell proliferation after 7 days when compared to fibronectin. Next, we evaluated the baseline behavior of healthy cells over a wide range of concentrations of stevioside, sucralose, and sucrose to narrow down the concentration ranges for further experimentation. We found that stevioside caused an overall decrease in the initial cell adhesion that was inversely proportional to the concentration of the sweetener present in the media. This reduction in adhesion was not observed for other sweeteners. In terms of cell proliferation, our data indicated that stevioside caused an overall increase in the proliferation of healthy cells at concentrations $<10 \mathrm{mg} / \mathrm{mL}$, but was lethal to cells at concentrations of $20 \mathrm{mg} / \mathrm{mL}$. Besides, the addition of sucralose to the media at any concentration caused a significant decrease in cell proliferation after 7 days, especially at higher concentrations. Sucrose, on the other hand, had no significant effects on cell proliferation at any concentration. At higher concentrations, both NNS caused significant changes in cell morphology to occur, with cells losing confluency and demonstrating aberrant morphology. Based on these data, we selected a narrower range of concentrations for each sweetener for use in our comparison of healthy and cancerous cells.

We then tested a narrower range of sweetener concentrations on both healthy and cancerous cells to determine the comparative effects of these sweeteners on both healthy and cancerous human fibroblasts. The results indicated that both stevioside and sucralose had a marked effect on the proliferation of cancerous fibroblasts that did not affect healthy cells as significantly. Sucralose exhibited an antiproliferative effect on both cell lines, but cancerous cells exhibited a $>5$-fold decrease in overall proliferation rates whereas healthy cells only exhibited a 3 -fold decrease when exposed to sucralose. Additionally, stevioside at concentrations $<5 \mathrm{mg} / \mathrm{mL}$ exhibited a proproliferative effect on healthy cell growth, promoting 1.5 -fold greater cell proliferation than no sweetener controls. Cancerous cells, on the other hand, had significantly reduced proliferation when exposed to stevioside when compared to no sweetener controls, with as much as a 13-fold decrease in proliferation that became greater with increasing concentrations of stevioside.

The study also measured the expression of integrins on healthy and cancerous cells treated with sweeteners to determine their effects on the cell's behavior. As determined from the cell proliferation assays, the addition of sucralose had an inhibitory effect on proliferation after 7 days, but the effect was more significant for cancer cells than healthy cells. Likewise, the study also observed that integrin expression was only mildly affected by the addition of sucralose to healthy cells but caused almost complete loss of integrin expression in cancer cells. Meanwhile, stevioside caused an increase in cell proliferation for healthy cells, but was extremely inhibitory to the growth of cancer cells. As before, stevioside had very little effect on integrin expression of healthy cells but caused loss of integrin expression in cancer cells. Finally, sucrose had little effect on the overall proliferation of healthy cells, but significantly reduced the proliferation of cancerous cells. As before, sucrose had little effect on healthy cells' integrin expression, but significantly reduced expression in cancer cells. Taken together, this data indicates that the sweeteners tested here, either directly or indirectly, induce a loss of integrin expression in the cancer cells that are not seen in healthy cells. It is unclear whether this loss of integrin expression is a mechanism by which the sweeteners act on the cells or an indirect consequence of some other cytotoxicity.
The use of NNS as a sweetener and foodstuff supplement is ubiquitous in many westernized cultures. Despite its widespread use, the data regarding the toxicological and dietary effects of these substances lack consensus and varies by the sweetener in question. ${ }^{16}$ Besides, many of the currently existing studies evaluating these substances are epidemiological, and there is not yet a dearth of literature on the effects of these sweeteners at a cellular level. Some sweeteners, such as stevioside, have been posited by researchers as having a potential anti-carcinogenic effect and have been proposed as potential anti-cancer drugs. ${ }^{17}$ Here we have evaluated the cytological effects of the sweeteners stevioside and sucralose on healthy human fibroblasts and human melanoma fibroblasts to determine the potential of these sweeteners to induce cytotoxicity.

Stevioside has been suggested in the past as having potential as an anti-cancer agent. ${ }^{17-20}$ Previous studies using stevioside have shown it has inhibitory properties on the proliferation of human osteosarcoma cells, ${ }^{17}$ breast cancer cells, ${ }^{19,20}$ and lung cancer cells. ${ }^{21}$ To date, there has been little research on the effect of steviosides on human melanoma cells. Here, we examined the differential cytotoxicity of stevioside on the proliferation of normal human fibroblasts versus melanoma derived fibroblasts. We observed that stevioside had an inhibitory effect on the proliferation of both cell lines, but the effect was more marked in the case of melanoma cells. A study of stevioside derivatives in lung cancer cells showed that these derivatives can cause p53 independent apoptosis. ${ }^{21}$ Since human melanoma tumors have a high incidence of $\mathrm{p} 53$ inactivating mutations, ${ }^{22}$ it can be useful to discover anti-tumor agents with p53 independent pathways of inducing apoptosis. Given the data produced here, stevioside seems to produce significant changes in the proliferation and integrin expression of melanoma cells, although further research is required to determine the mechanism by which this occurs.

Currently, the focus of a majority of the research into sucralose is on its toxicology and potential side effects of its ingestion. While anti-cancer properties of sucralose have not been evaluated in the literature, it was included in this study to determine if other NNS exhibited similar effects as stevioside in the treatment of cancer cells. The results were similar to that of stevioside, with sucralose having a marked inhibitory effect on the proliferation of both cell lines, but more significantly so on the melanoma cells. Sucralose was found to be more cytotoxic than stevioside in this case, with concentrations as low as $1 \mathrm{mg} / \mathrm{mL}$ still having an anti-proliferative effect on cells. FACS analysis showed that sucralose decreased $\alpha_{5}$ and $\beta_{1}$ expression in normal cells while stevioside showed no inhibitory effects, and both stevioside and sucralose decreased $\alpha_{5}$ and $\beta_{1}$ expression in cancerous cells.

The data generated during this study indicates that there is a differential cytological toxicity associated with of stevioside and sucralose between healthy and cancerous cells when exposed to the sweeteners in media. While the mechanism of cytotoxicity is unknown at this time, both sweeteners exhibited more marked effects on the cancerous cells than the healthy cells. Given these data, it is possible that the differential cytotoxic effects of these NNS could be leveraged for future research into anticancer treatments, as they have a greater effect on the proliferation of cancer cells than healthy cells. Future research should include the testing of these substances as an anti-tumor agent in the tumors of an in vivo system, such as SpragueDawley rats. Additionally, protein expression testing on oncogenes and apoptotic genes such as p53 could help determine the source of the differential cytotoxicity observed in cancer cells and explain the mechanism behind these sweeteners action on those cells. 


\section{Acknowledgements}

The authors would like to thank Melissa McCoy for supporting the group through the experiments and encouraging the research.

\section{Conflict of interest}

Authors declare that there is no conflict of interest.

\section{Funding details}

California State University Channel Islands: Extended University. Department of Biotechnology, Biomedical Engineering Emphasis. One University Drive, Camarillo, California 93012.

\section{References}

1. Adult Obesity Facts. Centers for Disease Control and Prevention; 2018.

2. Gardner C, Wylie-Rosett J, Gidding SS, et al. Nonnutritive Sweeteners: Current Use and Health Perspectives. Circulation. 2012;26(4):509-519.

3. Remsen I, Fahlberg C. Über die Oxydation des Orthotoluolsulfamids. Chemische Berichte. 1879;12:469-473.

4. Sylvetsky AC, Rother KI. Trends in the Consumption of Low-Calorie Sweeteners. Physiol Behav. 2016;164:446-450.

5. Brahmachari G, Mandal LC, Roy R, et al. Stevioside and Related Compounds - Molecules of Pharmaceutical Promise: A Critical Overview. Arch Pharm Chem. 2011;344(1):5-19.

6. Ilic V, Vukmirovic $\mathrm{S}$, Nebojsa $\mathrm{S}$, et al. Insight into anti-diabetic effect of low dose of stevioside. Biomedicine and Pharmacotherapy. 2017;90:216221.

7. Mathur S, Bulchandani N, Parihar S, et al. Critical Review on Steviol Glycosides: Pharmacological, Toxicological and Therapeutic Aspects of High Potency Zero Caloric Sweetener. International Journal of Pharmacology. 2017;13(7):916-928.

8. Rotimi SO, Rotimi OA, Adelani IB, et al. Stevioside modulates oxidative damage in the liver and kidney of high fat/low streptozocin diabetic rats. Heliyon. 2018;4(5)

9. Magnuson BA, Roberts A, Nestmann ER. Critical review of the current literature on the safety of sucralose. Food and Chemical Toxicology. 2017;106:324-355.
10. NHS. Eat Well: How safe is sucralose? 2019.

11. Roberts A, Renwick AG, Sims J, et al. Sucralose Metabolism and Pharmacokinetics in Man. Food and Chemical Toxicology. 2000;38:31-41.

12. Brusick D, Grotz VL, Slesinski R, et al. The absence of genotoxicity of sucralose. Food and Chemical Toxicology. 2010;48(11):3067-3072.

13. Eyk ADV. The effect of five artificial sweeteners on Caco-2, HT-29 and HEK-293 cells. Drug and Chemical Toxicology. 2015;38(3):318-327.

14. Geuns JM, Buyse J, Vankeirsbilck A, et al. Metabolism of Stevioside by Healthy Subjects. Experimental Biology and Medicine. 2007;232(1):164173.

15. Eckhart K, Vaghasia N, Kniseley A, et al. The effect of soft drink on proliferation, cell cycle analysis, and integrin expression of human foreskin fibroblast. Journal of Applied Biotechnology and Bioengineering. 7(4), 206-214.

16. Shankar P, Ahuja S, Sriram K. Non-nutritive sweeteners: Review and update. Nutrition. 2013;11(12):1293-1299.

17. Chen JM, Zhang J, Xia YM, et al. The natural sweetener metabolite steviol inhibits the proliferation of human osteosarcoma U2OS cell line. Oncology Letters. 2018. p. 5250-5256.

18. Takasaki M, Konoshima T, Kozuka M, et al. Cancer preventative agents. Part 8: Chemopreventive effects of stevioside and related compounds. Bioorg Med Chem. 2009;17(2):600-605.

19. Gupta E, Kaushik S, Purwar S, et al. Anticancer Potential of Steviol in MCF-7 Human Breast Cancer Cells. Pharmacognosy Magazine. 2017;13(51):345-350

20. Paul S, Sengupta S, Bandyopadhyay TK, et al. Stevioside Induced ROS-Mediated Apoptosis Through Mitochondrial Pathway in Human Breast Cancer Cell Line MCF-7. Nutrition and Cancer. 2012;64(7):1087-1094.

21. Malki A, Laha R, Bergmeier SC. Synthesis and cytotoxic activity of MOM-ether analogs of isosteviol. Bioorganic \& Medicinal Chemistry Letters. 2014;24(4):1184-1187.

22. Hocker T, Tsao H. Ultraviolet Radiation and Melanoma: A Systematic Review and Analysis of Reported Sequence Variants. Hum Mutat. 2007;28(6):578-588. 